\title{
IMPLEMENTASI AKAD MURABAHAH PADA PRODUK PEMBIAYAAN KREDIT PEMILIKAN RUMAH (KPR) DI BANK SYARIAH MANDIRI KC BOJONEGORO MENURUT HUKUM EKONOMI SYARIAH
}

\author{
Anis Muhtarom \& Warsidi \\ Email: anismuhtarom@gmail.com.
}

\begin{abstract}
This study discusses about how the implementation of the murabahah bil wakalah contract theory on mortgage products in the Bank Syariah Mandiri KC Bojonegoro is seen from the perspective of Sharia Economic Law. The scope of this research is limited to the following issues: (1) How is the implementation of the murabahah contract on mortgage loans in Bank Syariah Mandiri KC Bojonegoro? (2) How is the implementation of the murabahah contract on mortgage loan products in the Bojonegoro KC Mandiri Syariah Bank according to the Sharia Economic Law? This research includes the type of field research. Because this research was conducted at Bank Syariah Mandiri KC Bojonegoro. This research is a qualitative descriptive study because in this study the author will focus the discussion on legal facts in the form of the implementation of financing between banks and customers with murabahah contracts which will then be continued with a comparative analysis of the legal facts referred to as sharia economic law theories. This is intended to test the compatibility between legal theory and the legal practice in question.

The results of this research include: (1) The mechanism that must be taken to be able to receive financing for Public Housing Loans from Bank Syariah Mandiri KC Bojonegoro, is carried out through predetermined stages including: (a) submission; (b) BI checking / IDeb (debtor information); (c) the implementation of collateral estimates; (d) determination of ceilings; (e) Imputing data into a computer system; $(f)$ approval of the official for mortgage loans; $(g)$ Issuance of SP3 (Letter of Notification of Financing Approval); (h) Implementation of the contract which is attended by prospective customers, banks and notaries; (i) Disbursement. As for the agreements made between prospective customers and banks, there are elements as follows: (a) Contracting parties; (b) Sighat or iqab qabul akad murabahah; (c) Contract object. The object of the contract referred to in the housing loan product is a new or used house; (d) Nature of contract. Agreements are made clearly, both concerning objects, ceilings, time periods, contract places, financing nominal, margin obtained by the bank, and principal installments. In the event of default or bad credit where the customer is late in paying the installments, the bank's contribution will take the following steps: (a) Intensive billing; (b) Provision of Warning Letters 1, 2 and 3; (c) A restructuring offer (if the customer is pleased), ie installments are adjusted to the customer's ability and large at the end; (d) Voluntary guarantee selling offers; (e) Guaranteed auction. In a condition where the customer is not willing to carry out a contract restructuring, the bank offers that the auction of assets is a guarantee of the akah murabahah. As for the auction, the bank cooperates with a secret auction agency. (2) The implementation of housing loan financing with a murabahah contract in Bank Syariah Mandiri KC Bojonegoro is not in accordance with Sharia Economic Law originating from Law Number 21 of 2008 concerning Islamic Banking, MA Regulation Number 2 of 2008 concerning
\end{abstract}


Compilation of Sharia Economic Law and DSN-MUI fatwa Number 4 of 2000 concerning Murabahah.

Keywords: Contract, Murabahah bil Wakalah, KPR, BSM, Sharia Economic Law. PENDAHULUAN

Bank syariah adalah lembaga perbankan sebagaimana yang diatur dalam Undang-Undang, tetapi dalam kegiatan operasionalnya disesuaikan dengan prinsip-prinsip syariah Islam. Adapun prinsip tersebut yang paling mendasar adalah dalam tata cara bertransaksi harus menjauhi praktek-praktek yang dikhawatirkan mengandung unsur-unsur riba dan diganti dengan investasi atas dasar bagi hasil dan pembiayaan untuk keperluan usaha bisnis.

Di antara bank-bank yang menggunakan syariah Islam sebagai basis operasionalnya adalah Bank Syariah Mandiri (BSM). Seperti halnya bank syariah pada umumnya, Bank Syariah Mandiri pun memiliki berbagai produk pembiayaan yang di antara tujuannya adalah untuk membantu mengatasi permasalahan finansial serta untuk menjalin kedekatan hubungan dengan masyarakat. Berbeda dengan bank konvensional, produk pembiayaan yang ditawarkan oleh Bank Syariah Mandiri kepada masyarakat didasari pada prinsip-prinsip syariah dimana di dalam prosesnya terdapat akad sebagai pengikat, serta menggunakan sistem bagi hasil dan jual beli yang halal.

Sistem operasional perbankan dengan landasan syariah juga diterapkan oleh cabangcabang dari Bank Syariah Mandiri yang berlokasi di hampir setiap kabupaten, di antaranya adalah Bank Syariah Mandiri KC Bojonegoro. Bank Syariah Mandiri KC Bojonegoro memiliki beberapa produk pembiayaan unggulan seperti BSM Impalan, Pembiayaan Pensiun, Pembiayaan Griya BSM, Pembiayaan Kendaraan Bermotor, serta Pembiayaan Modal Kerja. Di antara produk-produk pembiayaan tersebut yang banyak diminati oleh masyarakat adalah produk pembiayaan Griya BSM atau yang dikenal dengan pembiayaan Kredit Pemilikan Rumah (KPR), yaitu model produk pembiayaan dalam jangka pendek, jangka menengah, maupun jangka panjang yang dimaksudkan untuk membiayai pembelian rumah tempat tinggal baik rumah baru maupun rumah bekas di lingkungan developer, dimana pembiayan tersebut menggunakan sistem murabahah. ${ }^{1}$

Kredit Pemilikan Rumah (KPR) merupakan salah satu bentuk fasilitas kredit yang diberikan oleh perbankan kepada masyarakat atau nasabah yang berkeinginan membeli rumah

\footnotetext{
${ }^{1}$ DeskTraining, Produk dan Jasa BSM, (Jakarta: PT. Bank Syariah Mandiri, 2010).
} 
baru maupun bekas dan pembayarannya dilakukan dengan cara angsuran. Apabila dilihat dari bentuknya, Kredit Pemilikan Rumah (KPR) ada dua macam, yaitu Kredit Pemilikan Rumah subsidi dan Kredit Pemilikan Rumah non subsidi. Kredit Pemilikan Rumah subsidi adalah kredit perumahan yang pembiayaannya mendapat bantuan atau subsidi dari pemerintah dalam bentuk potongan harga pokok, sedangkan Kredit Pemilikan Rumah non subsidi adalah kredit perumahan yang mana pembiayaannya dilakukan secara mandiri atau tidak mendapat bantuan subsidi dari pemerintah.

Berbeda dengan penerapan KPR pada bank konvensional yang menggunakan sistem bunga, penerapan KPR pada Bank Syariah Mandiri KC Bojonegoro dan bank syariah lainnya menerapkan sistem pembiayaan KPR dengan menggunakan model akad murabahah dan istishna'. ${ }^{2}$ Murabahah merupakan transaksi jual beli suatu barang ditambah dengan margin yang disepakati oleh para pihak dimana penjual memberikan informasi terlebih dahulu tentang harga jual barang kepada pembeli, serta menyebutkan jumlah keuntungan yang dikehendaki. Dalam hal ini bank bertindak sebagai penjual dan nasabah bertindak sebagai pembeli. Harga jual adalah harga beli bank dari pemasok ditambah dengan keuntungan. Harga tersebut harus dicantumkan dalam akad jual beli. Dalam akad tersebut, kedua belah pihak harus menyepakati harga jual beserta jangka waktu pembayaran. ${ }^{3}$

Dari kedua macam jenis pembiayaan KPR di atas - yakni pembiayaan KPR dengan sistem konvensional (sistem bunga anuitas (anuity rate) dan bunga flat (flat rate)) dan pembiayaan KPR dengan sistem akad murabahah - pembiayaan dengan akad murabahah tampaknya lebih menguntungkan karena pada akad ini nasabah mengetahui keseluruhan harga barang secara jelas, mulai dari harga jual ditambah dengan harga keuntungan yang ditentukan oleh bank sejak awal akad. Jumlah angsuran yang harus dibayar pun tidak naik turun hingga akhir karena tidak dipengaruhi oleh fluktuasi tingkat suku bunga sebagaimana yang terjadi pada bank konvensional.

Berdasarkan beberapa hasil temuan penelitian terdahulu didapati bahwa masih banyak bank-bank berbasis syariah yang menerapkan sistem akad murabahah dengan cara-cara yang tidak sesuai baik dengan fatwa DSN-MUI, Kompilasi Hukum Ekonomi Syariah, Undang-

\footnotetext{
${ }^{2}$ Istishna' adalah suatu transaksi jual beli narang dalam bentuk pemesanan pembuatan barang dengan kriteria dan persyaratan tertentu yang disepakati dengan pembayaran sesuai dengan kesepakatan. Lihat Muhammad. Manajemen Dana Bank Syariah. (Jakarta: Raja Grafindo Persada, 2014), 46-50.

${ }^{3}$ Biro Perbankan Syariah Bank Indonesia. Produk Perbankan Syariah. (Jakarta: Karim Business Consulting, 2001), 2.
} 
Undang Nomor 21 Tahun 2008 Tentang Perbankan Syariah, serta Fiqh Muamalah secara umum. ${ }^{4}$ Karena itu berdasarkan latar belakang di atas, mengingat pentingnya permasalahan tentang penerapan akad murabahah yang harus sesuai dengan hukum dan prinsip-prinsip ekonomi syariah ini, maka tujuan yang ingin dicapai melalui penelitian ini adalah untuk mengetahui secara mendalam tentang apakah transaksi akad murabahah yang dilakukan antara nasabah dan Bank Syariah Mandiri KC Bojonegoro berkaitan dengan pembiayaan KPR tersebut telah sesuai dengan hukum ekonomi syariah? Atas dasar itu penulis mengangkat penelitian ini dengan judul "Implementasi Akad Murabahah Pada Produk Pembiayaan Kredit Pemilikan Rumah (KPR) di Bank Syariah Mandiri KC Bojonegoro Menurut Hukum Ekonomi Syariah.”

Dalam penelitian ini penulis membatasi pokok-pokok permasalahan yang akan dijawab melalui penelitian ini meliputi: (1) Bagaimana implementasi akad murabahah pada produk pembiayaan kredit pemilikan rumah (KPR) di Bank Syariah Mandiri KC Bojonegoro? (2) Bagaimana implementasi akad murabahah pada produk pembiayaan kredit pemilikan rumah (KPR) di Bank Syariah Mandiri KC Bojonegoro menurut Hukum Ekonomi Syariah?

Penelitian ini termasuk jenis penelitian lapangan (field research). Karena seperti yang sudah dijelaskan bahwa penelitian ini dilakukan di Bank Syariah Mandiri KC Bojonegoro. Penelitian ini merupakan penelitian deskriptif kualitatif karena dalam penelitian ini penulis akan memfokuskan pembahasan pada fakta hukum berupa pelaksanaan pembiayaan antara bank dengan nasabah dengan akad murabahah yanng kemudian akan diteruskan dengan kajian analisis komparatif antara fakta hukum yang dimaksud dengan teori-teori hukum ekonomi syariah. Hal ini dimaksudkan untuk menguji kesesuaian antara teori hukum dengan praktek hukum yang dimaksud. Pendekatan yang digunakan dalam penelitian ini adalah pendekatan perbandingan (Comparative Approach). pendekatan perbandingan adalah model penelitian dengan cara memperbandingkan hukum teoritis dengan pelaksanaannya di lapangan. ${ }^{5}$ Pendekatan ini digunakan untuk melakukan analisis perbandingan guna menemukan kesesuaian dan ketidaksesuaian antara implementasi atau penerapan akad murabahah pada pembiayaan KPR di lokasi penelitian dengan hukum ekonomi syariah seperti yang tertuang dalam fatwa-fatwa DSNMUI dan Kompilasi Hukum Ekonomi Syariah. Selain hasil wawancara, observasi, dan dokumentasi, dalam penelitian ini sumber data primer yang akan digunakan antara lain: (1)

\footnotetext{
${ }^{4}$ Sebagai contoh adalah perkara sengketa akad murabahah yang diajukan di Pengadilan Agama Mataram dalam Putusan Hakim Perkara Nomor 0508/Pdt.G/2016/PA.Mtr Tentang Sengketa Akad Pembiayaan Murabahah.

${ }^{5}$ Peter Mahmud Marzuki. Penelitian Hukum. (Jakarta: Kencana, 2016), 172-174.
} 
Undang-Undang Republik Indonesia Nomor 21 Tahun 2008 Tentang Perbankan Syariah; (2) Fatwa DSN-MUI Nomor 4 Tahun 2000 tentang Akad Murabahah; dan (3) Kompilasi Hukum Ekonomi Syariah.

\section{PEMBAHASAN}

\section{A. Implementasi Akad Murabahah Pada Produk Pembiayaan Kredit Pemilikan Rumah (KPR) di Bank Syariah Mandiri KC Bojonegoro}

\section{Mekanisme Pembiayaan KPR di Bank Syariah Mandiri KC Bojonegoro}

Kredit Pemilikan Rumah (KPR) merupakan salah satu produk andalan yang ditawarkan oleh Bank Syariah Mandiri kepada masyarakat yang ingin memiliki rumah dengan cara angsuran dan dengan biaya awal yang ringan. Pada Bank Syariah Mandiri, mekanisme Kredit Pemilikan Rumah yang digunakan harus berdasarkan pada prinsip-prinsip syariah dan tidak boleh menyelisihinya. Seperti bank-bank lainnya yang menawarkan pembelian ruman dengan sistem kredit, Bank Syariah Mandiri KC Bojonegoro memiliki dua jenis kredit, yaitu Kredit Pemilikan Rumah Subsidi dimana pembiayaannya dibantu oleh pemerintah, dan Kredit Pemilikan Rumah Non Subsidi dimana pembiayaan dilakukan secara mandiri tanpa bantuan pemerintah.

Guna memenuhi banyaknya permohonan Kredit Pemilikan Rumah yang diajukan masyarakat, Bank Syariah Mandiri KC Bojonegoro saat ini telah melakukan kerja sama dengan beberapa developer perumahan yang ada di Kabupaten Bojonegoro dimana pembangunannya telah disesuaikan dengan peraturan Kementerian Pekerjaan Umum dan Perumahan Rakyat. Di antara Developer yang dipercaya untuk melaksanakan pembangunan perumahan dan telah melakukan kerja sama dengan pihak Bank Syariah Mandiri KC Bojonegoro adalah PT Luas Nusantara yang telah melakukan pembagunan kompleks perumahan di beberapa lokasi di sekitar Kota Bojonegoro. ${ }^{6}$

Bank Syariah Mandiri KC Bojonegoro memberikan pembiayaan Kredit Pemilikan Rumah umumnya kepada pasangan yang sudah menikah - namun dibolehkan juga bagi yang belum menikah - dan belum memiliki rumah dengan ketentuan salah satu pasangan atau pemohon tersebut telah memiliki pekerjaan yang tetap dan memiliki gaji tetap (fixed income) minimal Rp. 3.000.000 per bulan, usia pemohon minimal 21 tahun dan pada saat jatuh tempo pembiayaan usia

\footnotetext{
${ }^{6}$ Hasil wawaancara dengan Consumer Banking Relationship Manager di Bank Syariah Mandiri KC Bojonegoro, Farida Rochmawati, pada tanggal 20 Februari 2019.
} 
pemohon maksimal 55 tahun atau belum pensiun, sedangkan untuk wiraswasta dan professional usia maksimal 60 tahun. ${ }^{7}$ Untuk pemohon tidak diharuskan sebagai karyawan tetap suatu perusahaan, tetapi boleh apapun pekerjaannya selama memiliki penghasilan yang tetap per bulannya, seperti pedagang atau pekerja di berbagai bidang lainnya.

Apabila merujuk pada Peraturan Menteri Pekerjaan Umum dan Perumahan Rakyat Nomor 36 Pasal 10 Tahun 2016, masyarakat yang bekerja pada sektor informal dan tidak memiliki penghasilan tetap pun diperbolehkan untuk mengajukan Kredit Perumahan Rakyat dengan cara melakukan setoran secara harian atau mingguan pada bank pelaksana, karena dalam peraturan tersebut tidak dipersyaratkan bahwa pemohon harus memiliki penghasilan tetap. Meskipun demikian sejauh penelitian ini belum didapati pemohon dengan latar belakang pekerjaan diluar pegawai tetap suatu perusahaan. Hal tersebut disebabkan antara lain karena kurangnya informasi yang disosialisasikan oleh pihak Bank Syariah Mandiri KC Bojonegoro, adapun pertimbangan bank terkait resiko yang kemungkinan besar akan ditanggung oleh pihak bank manakala pemohon yang tidak memiliki penghasilan tetap sehingga kemungkinan terjadinya kredit macet akan semakin besar.

Adapun terkait dengan mekanisme yang harus ditempuh untuk dapat menerima pembiayaan Kredit Perumahan Rakyat dari Bank Syariah Mandiri KC Bojonegoro harus dilakukan melalui tahapan-tahapan berikut ini: ${ }^{8}$

(1) Nasabah melakukan pengajuan Kredit Perumahan Rakyat (KPR) ke Bank Syariah Mandiri KC Bojonegoro, nasabah menyerahkan persyaratan-persyaratan seperti fotokopi KTP suami istri, fotokopi KK, fotokopi surat nikah, fotokopi NPWP, IMB asli, SHM asli waktu akad, PBB bisa asli atau fotokopi, mutasi rekening gaji dan biasanya 6 bulan terakhir, slip gaji 3 bulan terakhir; fotokopi SK (wajib bagi pegawai tetap), kalau untuk pegawai wiraswasta (untuk sementara dihold), sedangkan untuk renovasi/pembangunan rumah wajib ada RAB (Rencana Anggaran Biaya).

(2) BI checking/ideb (informasi debitur) dari web OJK, menurut pihak bank jika ditemukan kolektibilitas-kolektibilitas maka permohonan akan langsung ditolak.

\footnotetext{
${ }^{7}$ Sumber informasi dari Brosur BSM Griya yang diterbitkan oleh Bank Syariah Mandiri KC Bojonegoro, diambil pada tanggal 5 Maret 2019.

${ }^{8}$ Hasil wawaancara dengan Consumer Banking Relationship Manager di Bank Syariah Mandiri KC Bojonegoro, Farida Rochmawati, pada tanggal 20 Februari 2019.
} 
(3) Pelaksanaan taksasi jaminan (penilaian jaminan rumah), minimal nilai jaminan harus mengcover $100 \%$ dari plafond, namun apabila nilai jaminan dibawah plafond maka ada tambahan jaminan.

(4) Setelah taksasi jaminan, proses berikutnya adalah penentuan plafond, analisa, serta konfirmasi tempat kerja pemohon.

(5) Pengimputan data ke sistem komputer untuk dihitung berapa plafond pembiayaan yang bisa diberikan. Hasil inputan sistem dimintakan review di bagian analis pembiayaan.

(6) Ketika hasil analisa sudah selesai, selanjutnya dimintakan persetujuan ke pejabat pemutus pembiayaan Kredit Pemilikan Rumah (KPR), ada kemungkinan plafond bisa sama dengan pengajuan atau bisa juga lebih rendah dari pengajuan.

(7) Setelah diputus oleh pejabat yang berwenang maka diterbitkan SP3 (Surat Pemberitahuan Persetujuan Pembiayaan) untuk diberikan kepada nasabah serta konfirmasi biaya-biaya yang diperlukan. Jika nasabah setuju, pihak bank akan membuatkan akad pembiayaan lengkap yang menjelaskan jenis barang, harga, biaya pegadaan barang jangka waktu pembayaran, jumlah angsuran dan mekanisme pelunasan

(8) Pelaksanaan akad yang dihadiri oleh calon nasabah, pihak bank, dan notaries. Setelah akad selesai dilaksanakan maka dokumen dikirim ke bagian pencairan pembiayaan Kredit Pemilikan Rumah (KPR).

(9) Pencairan di bagian pencairan. Hasil pencairan langsung masuk ke rekening nasabah untuk kemudian dilakukan pembayaran atas barang yang akan dibeli, yaitu rumah. Dalam hal ini pembelian barang yang diakadkan tidak dilakukan sendiri oleh bank, melainkan oleh nasabah.

Demikian mekanisme pelaksanaan akad murabahah pada produk pembiayaan Kredit Pemilikan Rumah yang dilaksanakan di Bank Syariah Mandiri KC Bojonegoro. Adapun untuk proses pengajuan produk Griya BSM sebagaimana dijelaskan tersebut biasanya membutuhkan waktu sekitar lima hari kerja berdasarkan proses standart yang digunakan oleh Bank Syariah Mandiri yang disebut dengan Service Level Agreement (SLA).

\section{Pelaksanaan Akad Murabahah KPR di Bank Syariah Mandiri KC Bojonegoro}

Menurut Consumer Banking Relationship Manager di Bank Syariah Mandiri KC Bojonegoro, Farida Rochmawati, akad yang digunakan dalam produk pembiayaan Kredit Pemilikan Rumah di Bank Syariah Mandiri KC Bojonegoro umumnya adalah akad murabahah 
bil wakalah (akad murabahah dengan wakalah), meskipun tidak menutup kemungkinan digunakannya akad-akad lainnya seperti akad istisna' (akad jual beli dengan pemesanan), atau akad ijarah muntahiya bit tamlik (akad sewa yang dilanjutkan dengan kepemilikan). Namun demikian akad-akad tersebut tampaknya jarang digunakan dalam produk pembiayaan Kredit Pemilikan Rumah, karena masyarakat di Bojonegoro umumnya lebih memilih menggunakan akad murabahah bil wakalah.

Apabila dilihat secara terminologis, akad murabahah bil wakalah merupakan akad jual beli dengan cara murabahah, yaitu dengan menjelaskan jenis, harga barang beserta keuntungan yang diminta, tetapi barang yang dipesan oleh calon pembeli atau nasabah tidak secara langsung dimiliki oleh penjual atau pihak bank, melainkan pembelian diwakilkan kepada pembeli atau nasabah untuk membeli barang yang diinginkannya dengan adanya wakalah atau penyerahan kuasa dari penjual atau pihak bank kepada nasabahnya. ${ }^{9}$

Pada produk pembiayaan Kredit Pemilikan Rumah di Bank Syariah Mandiri KC Bojonegoro pun jual beli murabahah dilakukan dengan cara demikian. Adapun pada akad yang dilakukan antara calon nasabah dengan bank, menurut pihak bank yang sempat penulis wawancarai, akad dilaksanakan dimana dalam akad tersebut terdapat hal-hal sebagai berikut:

(1) Pihak-pihak yang berakad. Pada pembiayaan Kredit Pemilikan Rumah, akad dilakukan oleh calon nasabah sebagai pembeli, perwakilan dari bank (biasanya diwakili oleh Kepala Cabang) sebagai penjual, dan Notaris sebagai pihak yang menjamin keabsahan akad.

(2) Sighat atau ijab qabul. Notaris membacakan ketentuan-ketentuan pembiayaan Kredit Pemilikan Rumah di hadapan nasabah dan pihak bank, dengan menyebutkan obyek, tempat akad, nominal pembiayaan secara terperinci seperti margin yang diperoleh bank, angsuran pokok ditambah dengan margin yang harus dibayar oleh nasabah, total angsuran secara keseluruhan, uang muka, jangka waktu, serta peraturan-peraturan yang ditetapkan oleh bank yang harus dipatuhi bersama antara nasabah dan bank. Kemudian pihak bank yang dalam hal ini adalah Kepala Cabang menawarkan pembiayaan yang telah dibacakan oleh notaris tersebut kepada calon nasabah yang terlibat dalam akad, dan calon nasabah kemudian memberikan jawaban untuk menerima atau menolak tawaran tersebut.

(3) Objek akad. Objek akad yang dimaksud dalam produk pembiayaan Kredit Pemilikan Rumah adalah rumah baru maupun bekas. Adapun objek akad ketika dilaksanakannya akad

\footnotetext{
${ }^{9}$ Ismail Nawawi, Fiqh Muamalah, 91-92.
} 
murabahah bil wakalah, adalah rumah yang - meskipun telah disebutkan spesifikasinya secara jelas - belum dibeli oleh penjual dalam akad murabahah tersebut, yaitu pihak bank.

(4) Sifat akad. Menurut pengakuan pihak bank, akad dilakukan secara jelas, baik menyangkut obyek, plafond, jangka waktu, tempat akad, nominal pembiayaan, margin yang diperoleh bank, angsuran pokok ditambah dengan margin yang harus dibayar oleh nasabah, total angsuran secara keseluruhan, uang muka, jangka waktu, serta peraturan-peraturan yang ditetapkan oleh bank yang harus dipatuhi bersama antara nasabah dan bank. Menurut pihak bank, perusahaan tidak menyebutkan harga karena pembiayaan KPR terikat peraturan Bank Indonesia, dimana untuk type rumah > 70 pembiayaan $70 \%$ maka down payment (DP) sebesar 20\% sehingga pembiayaan bisa sampai $80 \%$ dari harga rumah, kalau type rumah < 70 down payment (DP) sebesar 30\%. Adapun untuk pembiayaan rumah kedua maka down payment (DP) nail sebesar $10 \%$, dan seterusnya. ${ }^{10}$

Demikian beberapa poin yang terdapat dalam akad pembiayaan Kredit Pemilikan Rumah di Bank Syariah Mandiri KC Bojonegoro. Sejauh penelitian yang penulis lakukan, akad yang dilakukan antara nasabah dan pihak bank dilaksanakan denga adanya rasa sukarela antara keduanya, dan tidak ada paksaan dari pihak manapun. Menurut pihak bank, akad murabahah bil wakalah yang diterapkan untuk produk pembiayaan Kredit Pemilikan Rumah tersebut cukup mengundang minat masyarakat di sekitar kota Bojonegoro. Hal tersebut dibuktikan dengan semakin banyaknya pengajuan dari masyarakat yang setiap bulannya kurang lebih terdapat 2 hingga 3 nasabah, dimana kebanyakan digunakan untuk membeli rumah baru dan second. Adapun realisasinya sama dengan proses mekanisme pembiayaan KPR mulai dari pengajuan sampai dengan pencairan. ${ }^{11}$

\section{Permasalahan dan Penyelesaiannya}

Ketika penulis menanyakan mengenak permasalahan-permasalahan yang sering dihadapi terkait pelaksanaan akad murabahah pada produk pembiayaan Kredit Pemilikan Rumah kepada pihak bank, yang dalam hal ni diwakili oleh Consumer Banking Relationship Manager di Bank Syariah Mandiri KC Bojonegoro, Farida Rochmawati, ia menjelaskan bahwa di antara kendala yang pernah dihadapi dalam pelaksanaan Kredit Pemilikan Rumah adalah sebagai berikut:

\footnotetext{
${ }^{10}$ Hasil wawaancara dengan Consumer Banking Relationship Manager di Bank Syariah Mandiri KC Bojonegoro, Farida Rochmawati, pada tanggal 20 Februari 2019.

${ }^{11}$ Hasil wawaancara dengan Consumer Banking Relationship Manager di Bank Syariah Mandiri KC Bojonegoro, Farida Rochmawati, pada tanggal 20 Februari 2019.
} 
(1) Nama nasabah tidak bagus dari hasil BI checking. Misalnya ditemukan nama nasabah yang tidak baik yang pernah melakukan pemalsuan dokumen, maka nama nasabah tersebut langsung akan di blacklist dan nama tersebut akan disampaikan ke seluruh kantor cabang Bank Syariah Mandiri di seluruh Indonesia agar apabila melakukan pengajuan maka harus ditolak pengajuannya. Menurut pihak bank, hal ini merupakan salah satu contoh penerapan prinsip Prudencial Principle atau prinsip kehati-hatian sebagaimana yang diatur dalam Undang-Undang Nomor 21 Tahun 2008 tentang Perbankan Syariah.

(2) Jaminan tidak mengcover dan nasabah tidak ada jaminan lain.

(3) Nasabah membatalkan pngambilan KPR di tengah proses. Apabila hal tersebut terjadi, nasabah dapat dikenakan biaya administrasi saja, dan tidak ada denda apapun, karena bank menggunakan prinsip-prinsip syariah.

(4) Cash flow atau penghasilan nasabah tidak masuk DSR (Deep Service Ratio) / kecukupan nasabah untuk mengcover kredit terhadap total pendapatan. Apabila hal ini terjadi, maka biasanya bank tidak mengabulkan atau menolak permohonan kredit yang diajukan oleh nasabah.

Permasalahan-permasalahan tersebut pernah terjadi dan dialami oleh bank ketika berhubungan dengan calon nasabah yang tingkat ekonominya rendah atau tingkat ekonomi menengah ke bawah. Apabila permasalahan-permasalahan sebagaimana yang disebutkan di atas mengindikasikan kepada terjadinya wanprestasi dimana nasabah tidak bersedia lagi untuk membayar cicilannya, maka pibah bank akan melakukan beberapa langkah penyelesaian sebagai berikut:

(1) Penagihan secara intensif.

(2) Pemberian Surat Peringatan 1, 2, dan 3.

(3) Penawaran restruktur (jika nasabah berkenan), yaitu angsuran disesuaikan dengan kemampuan nasabah dan besar di akhir.

(4) Penawaran jual jaminan sukarela.

(5) Lelang jaminan.

Menurut penjelasan pihak Bank Syariah Mandiri KC Bojonegoro, dalam menghadapi masalah pembiayaan Kredit Pemilikan Rumah yang mengalami kredit macet, pihak bank sudah memiliki peraturan yang dapat dilaksanakan yang disebut dengan Standart Operating Procedure (SOP). Berdasarkan peraturan tersebut, apabila ada nasabah yang telat melakukan pembayaran 
maka akan secara langsung dihubungi melalui telpon untuk mengingatkan bahwa angsuran sudah waktunya dibayar. Apabila angsuran tidak juga dibayar, langkah berikutnya yang akan dilakukan oleh pihak Bank Syariah Mandiri adalah mengirimkan surat peringatan 1,2, dan 3. Surat peringatan 1 diberikan kepada nasabah yang telah mengalami keterlambatan pembayaran selama 30 hari. Sedangkan surat peringatan kedua dikeluarkan apabila nasabah terlambat melakukan pembayaran lebih dari 60 hari. Adapaun surat peringatan 3 dikeluarkan apabila nasabah mencapai keterlambatan pembayaran hingga 90 hari.

Apabila tidak kunjung dibayar maka akan ada utusan dari bank (debt collection) yang mendatanginya ke tempat dimana ia tinggal untuk menagih secara langsung. Apabila tidak juga dilakukan pembayaran misalnya karena nasabah tidak mampu membayar angsurannya, pihak bank akan melakukan penawaran dalam bentuk restrukturisasi akad. Hal ini dilakukan ketika terjadi permasalahan dimana dalam kondisi tertentu nasabah tidak lagi mampu melakukan pembayaran angsuran bukan karena wanprestasi, tetapi karena menurunnya kemampuan ekonomi nasabah, maka pihak bank akan melakukan koordinasi dengan nasabah dan melakukan penawaran restrukturisasi demi untuk penyelamatan nama nasabah di BI checking dimana pihak bank mengadakan restrukturisasi dengan menyesuaikan kemampuan nasabah. ${ }^{12}$

Dalam kondisi dimana nasabah tidak bersedia melakukan restrukturisasi akad, maka pihak bank menawarkan agar dilakukannya pelelangan terhadap harta yang menjadi jaminan pada akah murabahah tersebut. Keputusan pelelangan harta jaminan yang dilakukan harus berdasarkan pada persetujuan nasabah, dan tidak boleh ada paksaan apapun bentuknya. Adapun dalam pelaksanaan lelang tersebut pihak bank bekerja sama dengan lembaga lelang yang dirahasiakan, karena hal itu menjadi rahasia perusahaan yang dalam hal ini adalah Bank Syariah Mandiri KC Bojonegoro.

\section{B. Implementasi Akad Murabahah Pada Produk Pembiayaan Kredit Pemilikan Rumah (KPR) di Bank Syariah Mandiri KC Bojonegoro Menurut Hukum Ekonomi Syariah \\ 1. Mekanisme Pembiayaan KPR di Bank Syariah Mandiri KC Bojonegoro Menurut Hukum Ekonomi Syariah}

Untuk mengetahui apakah mekanisme pelaksanaan para produk pembiayaan Kredit Pemilikan Rumah dengan akad murabahah yang dipraktekkan oleh Bank Syariah Mandiri KC Bojonegoro sebagaimana dijelaskan sudah sesuai dengan hukum ekonomi syariah atau tidak,

\footnotetext{
${ }^{12}$ Hasil wawaancara dengan Consumer Banking Relationship Manager di Bank Syariah Mandiri KC Bojonegoro, Farida Rochmawati, pada tanggal 20 Februari 2019.
} 
maka terlebih dahulu penulis perlu menjelaskan bagaimana mekanisme pelaksanaan akad murabahah pada perbankan syariah menurut hukum ekonomi syariah.

Menurut Abd. Hadi, dalam pelaksanaan akad murabahah tanpa wakalah hendaknya melalui tahapan-tahapan berikut ini: (1) Nasabah mengajukan permohonan untuk melakukan pembelian suatu barang kepada pihak bank, kemudian bank memberikan persyaratan yang harus dilengkapi atas pengajuan nasabah tersebut; (2) Adanya kesempatan untuk melakukan penawaran atau negosiasi harga bagi kedua belah pihak, yaitu nasabah dan bank; (3) Setelah harga disepakati, bank sebagai penjual akan membeli barang dari produsen atau supplier berdasarkan pada spesifikasi yang dikehendaki oleh nasabah; (4) Ketika barang sudah dibeli oleh bank, bank dan nasabah yang memesan barang tersebut melakukan akad jual beli murabahah dengan kewajiban memenuhi seluruh syarat dan rukunnya; (5) Apabila akad telah selesai, supplier kemudian mengirimkan barang yang telah dibeli oleh bank ke alamat nasabah; (6) Apabila barang telah sampai ke alamat nasabah, maka nasabah menerima barang tersebut beserta dokumendokumennya secara lengkap; dan (6) Nasabah melakukan pembayaran angsuran secara rutin dalam jangka waktu yang telah disepakati, adapun nominal pembayaran tersebut mencakup jumlah margin dan pokoknya. ${ }^{13}$

Adapun apabila jual beli murabahah dilakukan dengan wakalah sebagaimana yang dilakukan pada pembiayaan Kredit Pemilikan Rumah di Bank Syariah Mandiri KC Bojonegoro, maka mekanismenya adalah sebagai berikut: (1) Nasabah membuat pengajuan kepada bank untuk pembeliah rumah baru maupun bekas dengan akad murabahah, kemudian bank meminta supaya nasabah melengkapi seluruh persyaratan yang diminta; (2) Bank memberikan surat penawaran (offering letter) kepada nasabah untuk melakukan pembelian barang dengan wakalah. Tujuan pemberian wakalah tersebut ialah agar nasabah dapat melakukan transaksi awal pembelian barang dengan supplier secara tidak tunai; (3) Nasabah membeli barang dari supplier berdasarkan pada akad wakalah yang telah disepakati, artinya nasabah membeli barang yang dimaksud secara tidak tunai; (4) Setelah barang dibeli, bank dan nasabah melakukan akad jual beli murabahah bil wakalah terhadap barang yang telah dibeli; dan (5) Nasabah melakukan

\footnotetext{
${ }^{13}$ Abd Hadi. Memahami Akad-Akad Dalam Perbankan Syariah dan Dasar Hukumnya. (Surabaya: Sinar Terang, 2015), 129.
} 
pembayaran angsuran kepada bank dalam jangka waktu yang telah disepakati sesuai nominal pembayaran yang mencakup jumlah margin dan pokoknya. ${ }^{14}$

Berdasarkan penjelasan di atas, mekanisme pelaksanaan pembiayaan Kredit Pemilikan Rumah di Bank Syariah Mandiri KC Bojonegoro tampaknya kurang sesuai dengan mekanisme jual beli murabahah dalam fiqh muamalah, baik murabahah bil wakalah maupun tanpa wakalah. Karena dalam jual beli murabahah baik bil wakalah maupun tanpa wakalah, barang yang menjadi objek akad harus telah menjadi milik dan dikuasai oleh bank sebagai penjual terlebih dahulu sebelum akad jual beli antara nasabah dan pihak bank dilaksanakan. Adapun dalam prakteknya, sebelum, pada saat, dan setelah akad murabahah dilakukan, barang masih belum menjadi milik bank sebagai penjual. Hal ini dapat dilihat pada mekanisme pelaksanaan pembiayaan Kredit Pemilikan Rumah di Bank Syariah Mandiri KC Bojonegoro pada tahap terakhir, yaitu pencairan dana ke rekening nasabah. Artinya, jual beli dengan akad murabahah pada pembiayaan Kredit Pemilikan Rumah di Bank Syariah Mandiri KC Bojonegoro dilakukan bil wakalah dengan cara memberikan otoritas kepada nasabah untuk secara langsung melakukan pembelian barang kepada supplier, tetapi pembelian tersebut dilakukan setelah akad jual beli murabahah disepakati. Padalah dalam fiqh muamalah pembelian bil wakalah harus dilakukan sebelum akad jual beli antara nasabah dengan pihak bank dilaksanakan.

Mengenai mekanisme pelaksanaan akad murabahah pada pembiayaan Kredit Pemilikan Rumah di Bank Syariah Mandiri, Undang-Undang Nomor 21 Tahun 2008 Tentang Perbankan Syariah tidak mengatur masalah tersebut. Adapun Peraturan Mahkamah Agung (PERMA) Nomor 2 Tahun 2008 Tentang Kompilasi Hukum Ekonomi Syariah, dijelaskan bahwa murabahah adalah pembiayaan saling menguntungkan yang dilakukan oleh pemilik barang dengan pihak yang membutuhkan melalui transaksi jual beli dengan disertai penjelasan bahwa harga pengadaan barang dan harga jual terdapat nilai lebih yang merupakan keuntungan atau laba bagi pemilik barang atau penjual dan pembayarannya dilakukan secara tunai atau angsur. ${ }^{15}$ Dari definisi tersebut dapat dipahami bahwa salah satu mekanisme jual beli murabahah pada perbankan syariah menurut Kompilasi Hukum Ekonomi Syariah adalah pembayarannya

\footnotetext{
${ }^{14}$ Ibid, 129-130.

${ }^{15}$ Kompilasi Hukum Ekonomi Syariah Pasal 20 Poin 6.
} 
dilakukan dengan cara angsuran. Namun demikian Kompilasi Hukum Ekonomi Syariah membolehkan pembayaran dilakukan secara tunai. ${ }^{16}$

Kompilasi Hukum Ekonomi Syariah pasal 116 menjelaskan bahwa Penjual harus membiayai sebagian atau seluruh jumlah dari harga pembelian barang yang telah disepakati spesipikasinya dengan pembeli, penjual juga harus membeli barang yang diperlukan pembeli atas nama penjual sendiri, dan pembelian ini harus bebas riba. Selain itu penjual harus memberi tahu secara jujur tentang harga pokok barang kepada pembeli seecara lengkap beserta biaya yang diperlukan untuk pengadaan barang tersebut. Selanjutnya pada pasal 119 dijelaskan bahwa apabila penjual hendak mewakilkan kepada pembeli untuk membeli suatu barang dari pihak ketiga, maka akad jual-beli murabahah harus dilakukan setelah barang secara prinsip sudah dikuasai atau menjadi milik penjual. Ketentuan ini diperkuat dengan pasal 120 yang menegaskan bahwa apabila penjual menerima permintaan dari pembeli akan suatu barang atau aset tertentu, maka penjual harus membeli terlebih dulu aset yang dipesan tersebut (sebelum akad jual beli murabahah dilaksanakan) dan pembeli harus menyempurnakan jual-beli yang sah dengan penjual.

Berdasarkan ketentuan-ketentuan mengenai jual beli dengan akad murabahah dalam Kompilasi Hukum Ekonomi Syariah pasal 116, 119, dan 120 tersebut, maka dapat penulis katakana bahwa mekanisme pelaksanaan akad murabahah pada pembiayaan Kredit Pemilikan Rumah di Bank Syariah Mandiri KC Bojonegoro tidak sesuai dengan ketentuan dalam Kompilasi Hukum Ekonomi Syariah. Karena Kompilasi Hukum Ekonomi Syariah mensyaratkan bahwa baik dalam akad murabahah bil wakalah maupun tanpa wakalah, objek akad, yaitu barang yang diperjualbelikan harus terlebih dahulu dimiliki oleh penjual atau pihak bank sebelum akad murabahah dilaksanakan, dan hal ini tidak terjadi pada akad pembiayaan Griya BSM. ${ }^{17}$

Fatwa DSN-MUI Nomor 4 Tahun 2000 mengatur tentang pelaksanaan akad murabahah. Pada bagian pertama yang mengatur ketentuan umum pelaksanaan akad murabahah dalam fatwa tersebut dijelaskan bahwa: (1) Pihak bank dan nasabah harus melakukan akad murabahah yang terbebas dari unsur riba; (2) Barang yang menjadi objek akad tidak diharamkan oleh syariah Islam: (3) Bank boleh melakukan pembiayaan sebagian atau seluruh harga pembelian barang atau objek akad yang telah disepakati kualifikasinya; (4) Bank membeli barang yang dipesan oleh nasabah atas

\footnotetext{
${ }^{16}$ Kompilasi Hukum Ekonomi Syariah Pasal 124.

${ }^{17}$ Kompilasi Hukum Ekonomi Syariah Pasal 116, 119, dan 120.
} 
nama bank sendiri, dan pembelian tersebut harus sah dan bebas dari unsur-unsur riba; (5) Bank harus menyampaikan semua hal yang berkaitan dengan pembelian barang, termasuk jika pembelian dilakukan dengan cara utang; (6) Bank kemudian menjual barang yang telah dibeli kepada nasabah atau pembeli dengan harga jual senilai harga beli ditambah dengan keuntungannya. Dalam hal ini Bank harus memberitahukan secara jujur harga pokok barang kepada nasabah beserta biaya yang dibutuhkan; (7) Nasabah harus membayar harga barang yang telah disepakati tersebut dalam jangka waktu tertentu yang telah disepakati bersama pihak bank; (8) Untuk mencegah terjadinya penyalahgunaan atau kerusakan akad tersebut, pihak bank dibolehkan membuat perjanjian khusus dengan nasabah; dan (9) Jika bank hendak mewakilkan kepada nasabah untuk membeli barang dari pihak ketiga, maka akad jual beli murabahah harus dilakukan setelah barang - secara prinsip - telah dikuasai atau menjadi milik bank.

Ketentuan tersebut apabila dibandingkan dengan pelaksanaan pembiayaan pembiayaan Kredit Pemilikan Rumah dengan akad murabahah di Bank Syariah Mandiri KC Bojonegoro, maka tampak ketidaksesuaiannya dengan ketentuan pada poin (4) dan (9) dimana objek akad haruslah benar-benar sudah menjadi milik penjual atau bank sebelum akad murabahah dilaksanakan. Ketentuan tersebut juga dikuatkan oleh ketentuan pada bagian kedua poin 2 dan 3 fatwa DSN-MUI Nomor 4 Tahun 2000 tersebut yang menyebutkan bahwa jika bank menerima permohonan tersebut, ia harus membeli terlebih dahulu aset yang dipesannya secara sah dengan pedagang, dan selanjutnya bank menawarkan aset tersebut kepada nasabah dan nasabah harus membelinya sesuai dengan janji yang telah disepakatinya, karena secara hukum janji tersebut mengikat; kemudian kedua belah pihak harus membuat kontrak jual beli. ${ }^{18}$ Demikian tahapan-tahapan jual beli dengan akad murabahah menurut fatwa DSN-MUI.

Ketentuan jual beli murabahah yang diatur dalam fatwa DSN-MUI Nomor 4 Tahun 2000 tersebut jelas menerangkan bahwa objek akad harus sudah menjadi milik penjual yang dalam hal ini adalah pihak bank sebelum akad murabahah dilaksanakan. Jadi, sampai di sini dapat disimpulkan bahwa mekanisme pelaksanaan pembiayaan pembiayaan Kredit Pemilikan Rumah dengan akad murabahah di Bank Syariah Mandiri KC Bojonegoro belum sesuai dengan aturan yang terdapat dalam fiqh muamalah, Peraturan Mahkamah Agung (PERMA) Nomor 2 Tahun 2008 Tentang Kompilasi Hukum Ekonomi Syariah, serta fatwa DSN-MUI Nomor 4 Tahun 2000 tentang Pembiayaan Murabahah.

\footnotetext{
${ }^{18}$ Fatwa DSN-MUI Nomor 4 Tahun 2000 tentang Pembiayaan Murabahah bagian kedua poin 2 dan 3.
} 


\section{Pelaksanaan Akad Murabahah KPR di Bank Syariah Mandiri KC Bojonegoro Menurut Hukum Ekonomi Syariah}

Untuk melihat apakah pelaksanaan akad murabahah pada pembiayaan Kredit Pemilikan Rumah di Bank Syariah Mandiri KC Bojonegoro telah sesuai dengan Hukum Ekonomi Syariah atau tidak, maka perlu kiranya dilihat terpenuhinya rukun dan syarat akad murabahah terlebih dahulu. Dalam fiqh muamalah, terdapat empat rukun yang harus terpenuhi untuk keabsahan akad murabahah berdasarkan pendapat mayoritas ulama, yaitu: ${ }^{19}$

\section{(1) Ijab Qabul}

Dalam ijab qabul disyaratkan adanya kejelasan maksud dalam bertransaksi, kesesuaian antara ijab dan qabul, kebersambungan dalam ijab dan qabul, serta menghindari hal-hal yang dapat membatalkan ijab dan qabul seperti penjual menarik kembali ucapannya, atau adanya penolakan dari pembeli. Berdasarkan hasil wawancara yang penulis lakukan dengan pihak bank, ijab qabul akad murabahah pada Kredit Pemilikan Rumah di Bank Syariah Mandiri KC Bojonegoro dilakukan dengan menyebutkan obyek, tempat akad, nominal pembiayaan secara terperinci seperti margin yang diperoleh bank, angsuran pokok ditambah dengan margin yang harus dibayar oleh nasabah, total angsuran secara keseluruhan, uang muka, jangka waktu, serta peraturan-peraturan yang ditetapkan oleh bank yang harus dipatuhi bersama antara nasabah dan bank. Karena itu penulis berpendapat bahwa pada rukun ini akad murabahah di Bank Syariah Mandiri KC Bojonegoro telah terpenuhi.

\section{(2) Pihak-pihak yang berakad}

Pelaku akad haruslah orang yang memiliki ahliyah (keduanya memiliki kepatutan dan kecakapan untuk melakukan transaksi menurut syariah, yakni berakal dan telah baligh) dan wilayah (memiliki kewenangan atau hak untuk melakukan transaksi atas suatu objek transaksi). Pada akad murabahah Kredit Pemilikan Rumah di Bank Syariah Mandiri KC Bojonegoro, akad dilakukan oleh calon nasabah sebagai pembeli, perwakilan dari bank (diwakili oleh Kepala Cabang) sebagai penjual, dan Notaris sebagai pihak yang menjamin keabsahan akad. Jadi pada rukun dan syarat ini pun akad murabahah Kredit Pemilikan Rumah telah terpenuhi. Karena telah terdapat penjual dan pembeli, yakni pihak bank dan nasabahnya. Adapun kedudukan notaris dalam hal ini tidak sebagai pihak yang ikut bertransaksi, melainkan hanya sebagai pihak yang menjamin keabsahan akad murabahah yang dilakukan antara nasabah dan pihak bank saja.

\footnotetext{
${ }^{19}$ Lihat Ismail Nawawi, Fiqh Muamalah, 92-93.
} 


\section{(3) Objek transaksi}

Harta yang dapat dikuasai dan memiliki manfaat, dapat dilihat dengan jelas spesifikasinya, serta bukan barang yang haram atau najis menurut syariah. Selain itu menurut Wahbah Zuhaili, objek transaksi harus berwujud ketika akad dilaksanakan, artinya barang yang diperjualbelikan melalui akad murabahah harus sudah ada pada saat akad sedang dilakukan, tidak dibolehkan bertransaksi atas objek yang belum jelas dan tidak hadir pada waktu akad, karena hal tersebut akan menimbulkan masalah ketika akan dilakukan serah terima. ${ }^{20}$

Objek akad yang dimaksud dalam produk pembiayaan Kredit Pemilikan Rumah adalah rumah baru maupun bekas. Adapun objek akad ketika dilaksanakannya akad murabahah bil wakalah, adalah rumah yang - meskipun telah disebutkan spesifikasinya - belum menjadi milik bank. Hal tersebut dapat dilihat pada adanya tahapan pencairan dana sebagai tahapan paling akhir dalam pelaksanaan pembiayaan Kredit Pemikilan Rumah sebagaimana dijelaskan sebelumnya. Artinya, objek akad yang berupa rumah baru akan dibeli oleh penjual (dengan mewakilkan pembelian kepada pembeli) setelah akad murabahah selesai. Dari sini dapat dipahami bahwa praktek semacam itu tidak sesuai dengan rukun dan syarat murabahah pada poin ini.

\section{(4) Sifat Akad}

Akad harus menunjukkan kejelasan maksud dari kedua belah pihak, artinya penjual mampuu memahami apa yang dimaksudkan oleh pembeli, dan sebaliknya. Selain itu antara ijab dan qabul harus sesuai, berada dalam satu majelis, dan pihak-pihak yang melakukan transaksi haruslah penjual dan pembeli. ${ }^{21}$ Menurut pihak bank, akad murabahah dilakukan secara jelas, baik menyangkut obyek, plafond, jangka waktu, tempat akad, nominal pembiayaan, margin yang diperoleh bank, angsuran pokok ditambah dengan margin yang harus dibayar oleh nasabah, total angsuran secara keseluruhan, uang muka, jangka waktu, serta peraturan-peraturan yang ditetapkan oleh bank yang harus dipatuhi bersama antara nasabah dan bank.

Sepintas akad murabahah Kredit Pemilikan Rumah di Bank Syariah Mandiri KC Bojonegoro telah sejalan dengan rukun dan syarat pada poin ini, tetapi apabila dilihat secara mendalam, penulis belum menemukan adanya akad wakalah dalam pembelian barang objek transaksi. Jika dilihat tahapan-tahapan pembiayaan murabahah yang dilaksanakan, akad

\footnotetext{
${ }^{20}$ Wahbah Zuhaili. Fiqh Islam wa Adillatuhu. (Beirut: Dar al-Fikr, 1989), 173-181.

${ }^{21}$ Ismail Nawawi, Fiqh Muamalah, 93-94.
} 
murabahah yang diterapkan adalah akad murabahah bil wakalah, sehingga selain akad murabahah, juga perlu adanya akad wakalah. Tetapi sejauh penelitian ini tidak penulis dapatkan bahwa telah dilakukan akad wakalah. Jadi, dapat disimpulkan bahwa syarat akad harus menunjukkan kejelasan maksud dari kedua belah pihak (yaitu maksud melakukan akad murabahah bil wakalah) pada poin ini belum terlaksana sepenuhnya.

Sampai di sini dapat penulis katakan bahwa pelaksanaan pembiayaan Kredit Pemilikan Rumah di Bank Syariah Mandiri KC Bojonegoro dengan akad murabahah belum sesuai dengan konsep murabahah menurut fiqh muamalah, baik dari aspek rukun maupun syaratnya.

Pada pasal 76 Kompilasi Hukum Ekonomi Syariah menyebutkan beberapa syarat obyek yang dapat diperjualbelikan antara lain: (1) barang yang diperjualbelikan harus sudah ada pada waktu akad dilaksanakan; (b) barang yang diperjualbelikan harus dapat diserahkan setelah akad selesai: (c) Barang yang diperjualbelikan harus dapat diketahui oleh pembeli; dan (d) Kekhususan barang yang dijualbelikan harus diketahui. Pada jual beli murabahah di Bank Syariah Mandiri KC Bojonegoro keempat syarat objek akad tersebut tidak terpenuhi.

Pada pasal 27 Kompilasi Hukum Ekonomi Syariah dijelaskan bahwa hukum akad terbagi ke dalam tiga kategori, yaitu akad yang sah, akad yang fasad atau dapat dibatalkan, dan akad yang batal atau batal demi hukum. Selanjutnya pasal 28 menjelaskan bahwa akad yang sah adalah akad yang telah terpenuhi rukun dan syarat-syaratnya, akad yang fasad adalah akad yang telah terpenuhi rukun dan syarat-syaratnya, akan tetapi terdapat segi atau hal lain yang merusak akad tersebut karena adanya pertimbangan maslahat, serta akad yang batal adalah akad yang kurang rukun dan atau syarat-syaratnya. ${ }^{22}$

Dalam fatwa DSN-MUI Nomor 4 Tahun 2000 tentang Murabahah bagian pertama dijelaskan bahwa: (1) Bank dan nasabah harus melakukan akad murabahah yang bebas riba; (2) Bank membeli barang yang diperlukan nasabah atas nama bank sendiri (bukan atas nama nasabah); dan (3) Pembelian ini harus sah dan bebas riba. Bank kemudian menjual barang tersebut kepada nasabah (pemesan) dengan harga jual senilai harga beli plus keuntungannya. Dari fatwa tersebut dapat dipahami bahwa akad yang dilakukan antara nasabah dan pihak bank pada pembiayaan murabahah haruslah akad yang bebas riba, pembelian barang objek akad apabila diwakilkan kepada nasabah maka haris dibeli atas nama bank dan dilakukan sebelum akad murabahah dilaksanakan. Setelah barang yang dipesan nasabah dibeli atas nama bank, kemudian bank menawarkan barang

\footnotetext{
${ }^{22}$ Kompilasi Hukum Ekonomi Syariah Pasal 27 dan 28.
} 
tersebut kepada nasabah dengan akad murabahah bil wakalah, setelah akad selesai kemudian barang diserahkan kepada nasabah dan nasabah membayar harga ditambah keuntungan bank secara angsuran.

Apabila dilihat dari perspektif Kompilas Hukum Ekonomi Syariah dan fatwa DSN-MUI Nomor 4 Tahun 2000 tentang Murabahah tersebut, akad murabahah yang dilakukan di Bank Syariah Mandiri KC Bojonegoro menurut penulis termasuk ke dalam akad yang batal, karena kurang terpenuhinya keabsahan rukun dan syarat-syarat akad, diantaranya: (1) Pelaksanaan pembiayaan yang dilakukan adalah pembiayaan murabahah bil wakalah, tetapi tidak ada akad wakalah; (2) Pelaksanaan wakalah berupa pembelian barang objek akad dilakukan tidak atas nama bank sebagai penjual, tetapi atas nama pembeli; dan (3) Pengadaan objek akad dilakukan setelah akad murabahah selesai.

\section{Penyelesaian Masalah yang Timbul Dalam Pembiayaan KPR di Bank Syariah Mandiri KC Bojonegoro Menurut Hukum Ekonomi Syariah}

Sebagaimana yang telah dijelaskan sebelumnya bahwa permasalahan yang biasanya muncul dari pelaksanaan pembiayaan Kredit Pemilikan Rumah dengan akad murabahah yang dilakukan di Bank Syariah Mandiri KC Bojonegoro adalah masalah kredit macet atau nasabah tidak atau telat membayar cicilan sesuai yang diperjanjikan dalam akad. Apabila hal tersebut terjadi, maka langkah-langkah yang akan ditempuh oleh pihak bank adalah: (1) Dilakukannya penagihan secara intensif; (2) Pemberian Surat Peringatan 1, 2, dan 3. Surat peringatan 1 diberikan kepada nasabah yang telah mengalami keterlambatan pembayaran selama 30 hari. Sedangkan surat peringatan kedua dikeluarkan apabila nasabah terlambat melakukan pembayaran lebih dari 60 hari. Adapaun surat peringatan 3 dikeluarkan apabila nasabah mencapai keterlambatan pembayaran hingga 90 hari; (3) Penawaran restrukturisasi akad (jika nasabah berkenan), yaitu pembaharuan akad dengan akad yang lain dan - misalnya pembaharuan akad murabahah dengan akad mudharabah dan sebagainya - angsuran disesuaikan dengan kemampuan nasabah; (4) Penawaran jual jaminan secara sukarela; dan (5) Lelang jaminan.

Dalam Kompilasi Hukum Ekonomi Syariah pasal 124 disebutkan bahwa: (1) Sistem pembayaran dalam akad murabahah dapat dilakukan baik secara tunai maupun cicilan dalam jangka waktu yang disepakati antara nasabah dengan pihak bank; (2) Dalam hal pembeli mengalami penurunan kemampuan untuk pembayaran cicilan, maka nasabah dapat diberi keringanan oleh pihak bank; dan (3) Keringanan sebagaimana dimaksud pada ayat (2) tersebut 
dapat diwujudkan dalam bentuk konversi dengan membuat akad baru untuk penyelesaian kewajiban. Apabila dilihat dari prosedur penyelesaian masalah pada pasal 124 ini, maka prosedur yang ditempuh oleh Bank Syariah Mandiri KC Bojonegoro tersebut telah sesuai dengan Kompilasi Hukum Ekonomi Syariah pada pasal 124.

Apabila nasabah tidak bersedia melakukan restrukturisasi akad, maka pihak bank menawarkan agar dilakukannya pelelangan terhadap harta yang menjadi jaminan pada akad murabahah tersebut. Perlu dipahami bahwa pelelangan dilakukan tidak berdasarkan pada habisnya masa pengembalian utang (masa angsuran), tetapi pada keterlambatan pembayaran hingga 90 hari. Artinya, meskipun masa pelunasan belum habis, pelelangan harta jaminan akan tetap dilakukan jika nasabah terlambat melakukan pembayaran angsuran hingga 90 hari.

Dalam fatwa DSN-MUI Nomor 4 Tahun 2000 Tentang Murabahah pada bagian kelima poin (2) disebutkan bahwa apabila nasabah menunda-nunda pembayaran dengan sengaja, atau jika salah satu pihak tidak menunaikan kewajibannya, maka penyelesaiannya dilakukan melalui Badan Arbitrasi Syari'ah setelah tidak tercapai kesepakatan melalui musyawarah. Selanjutnya pada bagian keenam fatwa tersebut mejelaskan bahwa apabila nasabah telah dinyatakan pailit dan gagal menyelesaikan utangnya, bank harus menunda tagihan utang sampai ia menjadi sanggup kembali, atau berdasarkan kesepakatan. ${ }^{23}$ Apabila prosedur penyelesaian masalah yang ditempuh oleh Bank Syariah Mandiri KC Bojonegoro tersebut dilihat berdasarkan fatwa DSN-MUI tersebut, maka dapat dikatakan bahwa prosedur tersebut tidak sesuai dengan fatwa DSN-MUI karena penyelesaian hanya dilakukan dengan cara melelang aset yang menjadi jaminan akad murabahah tersebut, tanpa melibatkan Badan Arbitrasi Syari'ah atau musyawarah terlebih dahulu.

Selain itu, pelelangan yang dilakukan tidak berdasarkan pada habisnya masa pengembalian utang (masa angsuran), tetapi pada keterlambatan pembayaran hingga 90 hari, berarti bahwa meskipun masa pelunasan belum habis, pelelangan harta jaminan akan tetap dilakukan jika nasabah terlambat melakukan pembayaran angsuran hingga 90 hari. Hal ini sama artinya dengan bank tidak memberi waktu penundaan tagihan utang sampai ia menjadi sanggup kembali, atau berdasarkan kesepakatan. Semestinya pelelangan dilakukan setelah masa pembayaran utang telah habis, bukan diukur dari keterlambatan pembayaran angsuran hingga 90 hari. Menurut penulis praktek penyelesaian masalah yang ditempuh oleh Bank Syariah Mandiri KC Bojonegoro secara umum tidak sesuai dengan fatwa DSN-MUI Nomor 4 Tahun 2000 Tentang Murabahah.

\footnotetext{
${ }^{23}$ fatwa DSN-MUI Nomor 4 Tahun 2000 Tentang Murabahah bagian kelima poin (2) dan bagian keenam.
} 
Dalam Undang-Undang Nomor 21 Tahun 2008 Tentang Perbankan Syariah pada pasal 55 disebutkan bahwa: (1) Penyelesaian sengketa Perbankan Syariah dilakukan oleh pengadilan dalam lingkungan Peradilan Agama; (2) Dalam hal para pihak telah memperjanjikan penyelesaian sengketa selain sebagaimana dimaksud pada ayat (1), penyelesaian sengketa dilakukan sesuai dengan isi Akad; dan (3) Penyelesaian sengketa sebagaimana dimaksud pada ayat (2) tidak boleh bertentangan dengan Prinsip Syariah.

Dalam kaitannya dengan prosedur penyelesaian masalah kredit macet pada Bank Syariah Mandiri KC Bojonegoro tersebut, apabila pelelangan dilakukan setekah habis masa angsuran, menurut penulis tidak menjadi masalah, yang mnejnadi masalah adalah ketika pelelangan dilakukan sebelum masa angsuran berakhir. Pada dasarnya semua akad syari'ah tidak berbasis bunga, sehingga semestinya tidak ada pengaruh waktu. Maka dalam Ekonomi Syariah, terdapat prinsip tidak boleh ada time velue of money yaitu prinsip yang menyebutkan bahwa uang sebesar satu rupiah yang diterima saat ini, lebih bernilai dibanding satu rupiah yang akan diterima pada waktu yang akan datang, karena prinsip ini merupakan ciri dari transaksi konvensional yang menjalankan prinsip bunga yang ribawi; Dengan kata lain bahwa dalam akad mudabahah secara hukum tidak dapat dibenarkan eksekusi lelang atas Hak Tanggungan atas dasar Wanprestasi atau keterlambatan pembayaran angsurandi tengahtengah masa angsuran masih berjalan atau masa angsuran belum berakhir. Jika demikian sama halnya menjalankan time-velue of money yang merupakan ciri menjalankan riba al-nasi'ah yaitu riba karena penagguhan. Dengan kata lain, bahwa dalam eksekusi lelang atas Hak Tanggungan untuk pembayaran seluruh harga yang disepakati harus menunggu sampai berakhirnya masa angsuran. Berdasarkan argumentasi ini dapat penulis simpulkan bahwa prosedur penyelesaian masalah kredit macet pada Bank Syariah Mandiri KC Bojonegoro tersebut selain tidak sejalan dengan Undang-Undang Nomor 21 Tahun 2008 Tentang Perbankan Syariah pada pasal 55 poin (3) di atas.

\section{KESIMPULAN}

Berdasarkan kajian di atas dapat penulis simpulkan bahwa secara umum pelaksanaan pembiayaan Kredit Pemilikan Rumah dengan akad murabahah di Bank Syariah Mandiri KC Bojonegoro tidak sesuai dengan Hukum Ekonomi Syariah karena adalah beberapa realitas berikut ini: (1) Pelaksanaan pembiayaan yang dilakukan adalah pembiayaan murabahah bil wakalah, tetapi tidak ada akad wakalah; (2) Pelaksanaan wakalah berupa pembelian barang objek akad dilakukan tidak atas nama bank sebagai penjual, tetapi atas nama pembeli; dan (3) Pengadaan objek akad dilakukan setelah akad murabahah selesai; dan (4) Pelaksanaan 
pelelangan aset jaminan dilakukan tidak berdasarkan pada telah habisnya masa angsuran, melainkan berdasarkan keterlambatan pembayaran angsuran selama 90 hari jika nasabah tidak bersedia melakukan restrukturisasi akad. Menurut pendapat penulis, agar akad jual beli murabahah dan pelaksanaannya sah menurut Hukum Ekonomi Syariah, maka harus dilaksanakan secara benar-benar sesuai dengan ketentuan-ketentuan yang telah ditetapkan dalam Hukum Ekonomi Syariah.

\section{DAFTAR PUSTAKA}

Al-Kasani, Abu Bakar Ibn Mas’ud. Bada'i wa al-Sana' fi Tartib al-Syara'i, Jilid 4. Beirut: Dar Al-Arabi, t.th.

Al-Qardhawi, Yusuf. Halal wa Haram fi al-Islam. Kairo: Dar al-Makrifah, th.

Al-Syaukani Muhammad bin Ali. Naylul Authar, juz 6. ttp: Dar al-Fikr, tth.

Amar, Faozan. Ekonomi Islam, Suatu Pengantar. Jakarta: Uhamka Press, 2016.

Antonio, Muhammad Syafi'i. Bank Syariah Dari Teori ke Praktik. Jakarta : Gema Insani Press, 2016.

Antonio, Syafi'i. Apa dan Bagaimana Bank Islam. Yogyakarta: Dana Bakti Wakaf, 1992.

Arifin Zainal. Mekanisme Kerja Perbankan Islam dan Permasalahannya. Jurnal Hukum Bisnis, Volume 11, 2000.

Biro Perbankan Syariah Bank Indonesia. Produk Perbankan Syariah. Jakarta: Karim Business Consulting, 2001.

DeskTraining, Produk dan Jasa BSM, Jakarta: PT. Bank Syariah Mandiri, 2010.

Djamil, Fathurrahman. Hukum Ekonomi Islam. Jakarta: Sinar Grafika, 2015.

Doi, Abdurrahman I. Shariah: The Islamic Law. Kuala Lumpur-AS Noordeen, 1984.

Hasan, M. Iqbal. Metodologi Penelitian dan Aplikasinya, Bogor: Ghalia Indonesia, 2002.

Lubis, Suhrawardi K. Hukum Perjanjian Dalam Islam.(Jakarta: Sinar Grafika, 1996.

Mannan, M. A. Ekonomi Islam: Teori dan Praktek. Jakarta: PT. Intermasa, 1992.

Marzuki, Peter Mahmud. Penelitian Hukum. Jakarta: Kencana, 2016.

Moleong, Lexy J. Metodologi Penelitian Kualitatif. Bandung: Ramaja Rosdakarya, 2014.

Muhammad. Manajemen Dana Bank Syariah. Jakarta: Raja Grafindo Persada, 2014.

Muslih, Ahmad Wardi. Fiqh Muamalah. Jakarta: Amzah, 2013.

Nawawi, Ismail. Fiqh Muamalah Klasik dan Kontemporer. Bogor: Ghalia Indonesia, 2012. 
Purhantara, Wahyu. Metode Penelitian Kualitatif untuk Bisnis. Yogyakarta: Graha Ilmu, 2014.

Ridha, Muhammad Rasyid. Tafsir al-Manar, jilid 3. Mesir: Dar al-Manar, 1376 H.

Sabiq, Sayid. Fiqh Sunnah. Jilid 11. Bandung: PT al-Ma’arif, 1987.

Shomad, Abd. Hukum Islam: Penormaan Prinsip Syariah Dalam Hukum Indonesia. Jakarta: Kencana, 2010.

Suadi, Amran. Abdul Manan Ilmuan dan praktisi Hukum kenangan sebuah perjuangan. Jakarta Kencana 2016.

Syafe'i, Rahmat. Fiqh Muamalah. Bandung: CV Pustaka Setia, 2001. 